\title{
PEMAHAMAN GURU FISIKA TENTANG IMPLEMENTASI KURIKULUM 2013 (K-13) PADA PEMBELAJARAN FISIKA DI MTs DARUL ULUM
}

\author{
Effendi $^{1^{*}}$, Alimatu Fatmawati ${ }^{2}$, Umi Kalsum ${ }^{3}$ \\ Program Studi Pendidikan Fisika STKIP Nurul Huda Sukaraja \\ ${ }^{*}$ Coressponding author: effendi@ stkipnurulhuda.ac.id
}

Article History:

Received: maret 03, 2021

Revised: april 21, 2021

Accepted: mei 23, 2021

Published: juni 24, 2021

Keywords: Kurikulum 2013, pemahaman guru fisika, pembelajaran fisika

\begin{abstract}
This study aims to analyze the understanding of physics teachers at MTs Darul Ulum Karang Sari about K13 (2013 Curriculum), teacher readiness in learning, implementation of learning, and direction of learning development. The research on the understanding of physics teachers was carried out using a qualitative descriptive research method. The research subjects were four physics teachers at MTs Darul Ulum Karang Sari. Data was collected using interview and questionnaire techniques. The data were analyzed and classified by presenting the data, reducing the data, and making conclusions from the data. Based on the results of the study, it can be concluded that the physics teacher at MTs Darul Ulum has not fully understood the concept of the 2013 curriculum. Some teachers are more focused on character education contained in $K$ 13. This understanding that focuses on character education has an impact on unclear learning objectives. The readiness of the physics teacher at MTs Darul Ulum to start learning is in accordance with the syllabus and lesson plans, although it is not optimal. For example, the teacher has prepared materials, methods, and media that will be used in learning. However, in the implementation, not all teachers do according to the 2013 curriculum. In the implementation in the classroom learning with the 2013 curriculum does not really show the difference with learning with KTSP. The assessment system has been done well by most teachers.
\end{abstract}

\footnotetext{
Abstrak: Penelitian ini bertujuan untuk menganalisis pemahaman guru fisika MTs Darul Ulum Karang Sari tentang K13, kesiapan guru dalam pembelajaran, implementasi, dan arah pengembangan pembelajaran. Penelitian terhadap pemahaman guru fisika ini dilakukan dengan menggunakan metode penelitian deskriptif kualitatif. Subyek penelitian yang dideskripsikan empat orang guru fisika MTs Darul Ulum Karang Sari. Pengumpulan data dilakukan dengan menggunakan teknik wawancara dan angket. Kemudian data yang dikumpulkan tersebut dianalisis dan diklasifikasikan dengan melakukan penyajian data, reduksi data dan pada akhirnya ditarik kesimpulan dari data tersebut. Berdasarkan hasil penelitian dapat disimpulkan bahwa Guru fisika MTs Darul Ulum belum sepenuhnya memahami konsep kurikulum 2013. Namun sebagian guru lebih berfokus pada pendidikan karakter yang terkandung dalam K13. Pemahaman yang berfokus pada pendidikan karakter ini berdampak pada tujuan belajar yang tidak jelas. Kesiapan guru fisika MTs Darul Ulum untuk memulai pembelajaran sudah sesuai dengan acuan silabus dan RPP walaupun belum maksimal, seperti menyiapkan materi, metode, dan media yang akan digunakan dalam pembelajaran. Namun dalam pelaksanaan tidak semua guru melakukan sesuai dengan kurikulum 2013. Pada pelaksanaan di dalam kelas pembelajaran dengan kurikulum 2013 tidak begitu menampakkan perbedaan dengan pembelajaran dengan KTSP. Sistem penilaian sudah bisa dilakukan dengan baik oleh sebagian besar guru.
} 


\section{PENDAHULUAN}

Konsep kurikulum berkembang sejalan dengan perkembangan teori dan praktik pendidikan serta bervariasi sesuai dengan aliran atau teori pendidikan yang diterapakan (Baharun, 2017; Khoeriyah, 2021; Wekke \& Astuti, 2017). Kurikulum 2013 (K-13) merupakan pengembangan Kurikulum Tingkat Satuan Pendidikan (KTSP) diterapkan di Indonesia (Kemendikbud, 2018). Kurikulum diharapkan mampu membawa pembaruan pada Pendidikan Indonesia. Sejak tahun 2013 lalu Kementrian Pendidikan Nasional memberikan himbauan kepada sekolah yang telah siap untuk beralih dari Kurikulum Tingkat Satuan Pendidikan ke Kurikulum 2013. Oleh sebab itu, kurikulum ini masuk dalam masa percobaan dengan menjadikan sekolahsekolah yang menerapkannya sebagai sekolah percobaan. Keputusan ini diambil karena Kurikulum 2013 dinilai mampu membangun peserta didik menjadi pribadi yang lebih mandiri (Mulyasa, 2013).

Pada tahun 2015, Kementrian Pendidikan Nasional dan Kebudayaan membebaskan sekolah-sekolah seluruh Indonesia untuk tetap menggunakan K-13 atau kembali pada kurikulum sebelumnya yaitu Kurikulum Tingkat Satuan Pendidikan (KTSP). Keputusan tersebut dapat meringankan sekolah-sekolah yang belum siap melaksanakan K-13. Sehingga pada kenyataannya tidak sedikit sekolah baik swasta maupun negeri di luar sekolah percontohan yang tetap memilih menggunakan K-13 (Oktaviana et al., 2016; Wina et al., 2017).

K-13 pada tahun 2014 sudah diterapkan pada beberapa kelas di tingkat pendidikan Sekolah Dasar, Menengah Pertama, dan Menengah Atas. K-13 menitik beratkan penilaiannya pada tiga aspek yaitu: (a) aspek pengetahuan, (b) aspek keterampilan, dan (c) aspek sikap dan perilaku. Karena itu dalam penerapan $\mathrm{K}-13$, banyak materi pada pembelajaran yang disederhanakan atau ditambahkan (Kemendikbud, 2013; Oktavianti et al., 2015).

Pada penerapannya banyak materi pada satu mata pelajaran yang disisipkan dalam materi mata pelajaran lain. Hal ini dimaksudkan agar pengetahuan peserta didik di Indonesia dalam mempelajari suatu materi dapat tersusun secara utuh dari berbagai disiplin ilmu. Selain itu dengan K-13 diharapkan pengetahuan peserta didik di Indonesia setara dengan pengetahuan peserta didik tingkat Internasional (Panduan Penyusunan Kurikulum Tingkat Satuan Pendidikan Jenjang Pendidikan Dasar Dan Menengah, 2006; Kemdikbud, 2014).

Pada K-13 terdapat sistem pembelajaran baru dimana peserta didik jurusan tertentu diperbolehkan mengikuti pembelajaran di kelas jurusan yang berbeda dengan syarat tertentu. Sehingga, peserta didik dapat lebih aktif dalam membangun pengetahuannya dalam proses pembelajaran serta membuka kesempatan bagi peserta didik tingkat Menengah Pertama agar dapat memperdalam ilmu yang dipelajari. Diterapkannya K-13 tentu membawa banyak sekali perubahan dalam persiapan hingga teknik pengajaran, mulai dari pembuatan instrumen kegiatan pembelajaran hingga proses pembelajaran di kelas itu sendiri.

Hal ini membawa banyak sekali pendapat tentang penerapan K-13 pada proses pembelajaran di kelas khususnya pada tingkat Sekolah Menengah Pertama. Beberapa tenaga pengajar memilih untuk "Pro" namun yang lain memilih "Kontra" terhadap kurikulum ini (Inzanah et al., 2014; Rakhmawati et al., 2016).

Pada pelaksanaan K-13 di daerah, masih terdapat berbagai persoalan. Meski tujuan kurikulum itu baik, namun pelaksanaan di lapangan harus mendapat banyak perbaikan. Persoalan-persoalan yang muncul dalam penerapan K-13 
antara lain keterbatasan pengetahuan yang diperoleh oleh guru, sekolah, dan lembaga yang bertanggungjawab, penerapan yang dinilai terlalu mendadak dan kesiapan semua perangkat pendukung yang belum maksimal. K-13 berdampak kepada tuntutan kompetensi guru, dimana guru dituntut memiliki kemampuan yang relevan dengan karakteristik kurikulum. Diharapkan dengan kemampuan yang dimiliki oleh para guru dapat memperlancar dalam implementasi kurikulum 2013 (Albantani, 2015).

Kabupaten Ogan Komering Ulu (OKU) Timur merupakan salah satu kabupaten di Provinsi Sumatera Selatan dengan tingkat kelulusan tertinggi pada ujian nasional tingkat Sekolah Menengah Pertama yang dilangsungkan setiap tahun. Kabupaten OKU Timur juga dikenal dengan pertumbuhan ekonomi yang sangat pesat. Hal ini dapat menjadi indikator bagaimana kualitas sumber daya manusia di Kabupaten OKU Timur. Dengan demikian, Kabupaten OKU Timur masih sangat kental dengan budaya dan adat istiadatnya. Kuatnya adat budaya sedikit banyak menjadi kebiasaan hidup yang membentuk karakter masyarakat, khususnya pelajar. Karakter masyarakat Indonesia bagian barat yang di dalamnya termasuk Provinsi Sumatera Selatan lebih spesifik lagi, Kabupaten OKU Timur cenderung lebih keras dan kukuh. Karakter ini dibawa sejak masih menyandang status pelajar.

Melihat karakter dari pelajar OKU

Timur, K-13 sesuai dengan kebiasaan belajar para pelajar. Karakter para pelajar yang keras membuat pelajar lebih senang mengeksplor pengetahuannya sendiri dibanding "disetir" oleh guru. Selain itu penilaian pada 3 hal utama yang ditekankan oleh K-13 mau tidak mau akan menekan kebiasaan buruk yang disebabkan oleh karakter peserta didik yang keras. Namun, sebelum dapat berjalan dengan baik, guru dituntut memiliki pemahaman yang benar tentang K-13 dan bagaimana implementasinya dalam proses pembelajaran. Melihat kebijakan pemerintah dinas bahwa telah direncanakan dan dilaksanakan adanya sosialisasi tentang implementasi kurikulum 2013 di sekolah-sekolah. namun terlaksanannya sosialisasi disekolah-sekolah hanya ditunjuk beberapa guru, termasuk guru MTs Darul Ulum Karangsari. Menurut guru fisika MTs Darul Ulum, pemahaman guru fisika tentang implementasi kurikulum 2013 di MTs Darul Ulum belum maksimal. Padahal di MTs Darul Ulum Karangsari telah ditetapkan menggunakan kurikulum 2013 sebagi pegangan.

Pada penetapan kurikulum 2013 di MTs Darul Ulum Karangsari secara otomatis guru wajib memahami kurikulum 2013. Karena Guru sangat berpengaruh terhadap pelaksanaan K-13. Sehingga sangatlah perlu untuk mengetahui bagaimana pemahaman para guru tentang K-13 dan arah pengembangan pembelajaran khususnya di MTs Darul Ulum Karangsari.

Peneliti sebelumnya telah menerapkan kurikulum melalui pengembangan perangkat pembelajaran (Inzanah et al., 2014), penilaian autentik (Yubali, 2013), dan penerapan kurikulum di sekolah dasar (Albantani, 2015; Djuanda, 2014; Josip \& Sinambela, 2013; Wekke \& Astuti, 2017). Fokus penelitian ini menganalisis implementasi pembelajaran menggunakan kurikulum 2013 di madrasah tsanawiyah.

\section{METODE}

Penelitian ini dilakukan di MTs Darul Ulum Karang Sari pada tahun 2020. Penelitian ini merupakan penelitian kualitatif. Pengumpulan data dalam penelitian ini menggunakan wawancara, angket, observasi, dan dokumentasi. Teknik analisis data dalam penelitian ini dilakukan dengan cara menghitung hasil 
angket, wawancara dan dokumentasi. Analisis data digunakan untuk melihat tentang pemahaman guru fisika tentang implementasi kurikulum 2013 pada pembelajaran fisika di MTs Darul Ulum Karangsari.
Hasil dari penelitian ini berupa hasil angket pemahaman guru, hasil wawancara, dan dokumentasi. Adapun angket diberikan kepada empat orang guru dengan hasil pemahaman guru 1 seperti pada tabel 1 .

\section{HASIL DAN PEMBAHASAN}

Tabel 1. Hasil Angket Pemahaman Guru Fisika 1

\begin{tabular}{|c|c|c|c|c|c|c|c|}
\hline \multirow{2}{*}{ Aspek } & \multirow{2}{*}{ Indikator } & \multicolumn{4}{|c|}{ Jumlah skor } & \multirow{2}{*}{$\begin{array}{c}\text { Rata- } \\
\text { rata }\end{array}$} & \multirow{2}{*}{ Kategori } \\
\hline & & G1 & G2 & G3 & G4 & & \\
\hline $\begin{array}{l}\text { Persiapan } \\
\text { pembelajaran }\end{array}$ & $\begin{array}{l}\text { a. Menerima } \\
\text { pengarahan } \\
\text { kurikulum } 2013 \\
\text { b. Penetapan kriteria } \\
\text { hasil pencapaian } \\
\text { peserta didik } \\
\text { c. Menyusun RPP } \\
\end{array}$ & $\begin{array}{l}75 \% \\
100 \% \\
100 \% \\
\end{array}$ & $\begin{array}{l}100 \% \\
100 \% \\
75 \% \\
\end{array}$ & $\begin{array}{r}100 \% \\
100 \% \\
100 \% \\
\end{array}$ & $\begin{array}{r}75 \% \\
100 \% \\
75 \% \\
\end{array}$ & $91,2 \%$ & Sangat tinggi \\
\hline $\begin{array}{l}\text { Pelaksanan } \\
\text { pembelajaran }\end{array}$ & $\begin{array}{l}\text { a. Menjelaskan } \\
\text { kompetensi } \\
\text { b. Mengajarkan bahan } \\
\text { fisika } \\
\text { c. Observasi } \\
\text { d. Menanya } \\
\text { e. Eksperimen } \\
\text { pengumpulan } \\
\text { invormasi } \\
\text { f. Mengasosiasi } \\
\text { g. Mengkomunikasi } \\
\text { h. Pembelajaran } \\
\text { integratif } \\
\text { i. Menguasai metode } \\
\text { pembelajaran dan } \\
\text { pendekatan yang } \\
\text { sesuai kurikulum } \\
\text { 2013 } \\
\text { j. Menguasai } \\
\text { pengelolaan kelas } \\
\text { k. Menguasai media } \\
\text { media pembelajaran } \\
\text { 1. Praktikum }\end{array}$ & $\begin{array}{c}75 \% \\
100 \% \\
75 \% \\
100 \% \\
75 \%\end{array}$ & $\begin{array}{c}100 \% \\
100 \% \\
100 \% \\
75 \% \\
75 \%\end{array}$ & $\begin{array}{r}100 \% \\
100 \% \\
100 \% \\
100 \% \\
75 \% \\
\\
75 \% \\
100 \% \\
75 \% \\
100 \% \\
100 \% \\
100 \% \\
100 \% \\
\end{array}$ & $\begin{array}{c}100 \% \\
75 \% \\
100 \% \\
75 \% \\
100 \% \\
\\
75 \% \\
100 \% \\
100 \% \\
100 \% \\
\\
75 \% \\
100 \% \\
75 \%\end{array}$ & $89,6 \%$ & Sangat tinggi \\
\hline $\begin{array}{l}\text { Penilaian } \\
\text { pembelajaran }\end{array}$ & $\begin{array}{l}\text { a. Melakukan penelitian } \\
\text { sesuai dengan } \\
\text { kurikulum } 2013 \\
\text { b. Menyusun dan } \\
\text { menggunakan } \\
\text { instrumen penilaian } \\
\text { aspek sikap, } \\
\text { pengetahuan, dan } \\
\text { keterampilan peserta } \\
\text { didik } \\
\text { c. Ulangan harian dan } \\
\text { penilaian proyek } \\
\text { d. Membuat laporan } \\
\text { penilaian } \\
\text { e. Mengadakan } \\
\text { remedial } \\
\end{array}$ & $\begin{array}{l}75 \% \\
100 \% \\
75 \%\end{array}$ & $\begin{array}{r}100 \% \\
75 \% \\
100 \%\end{array}$ & $\begin{array}{l}75 \% \\
100 \% \\
100 \%\end{array}$ & $\begin{array}{l}100 \% \\
75 \% \\
100 \%\end{array}$ & $87,5 \%$ & Sangat tinggi \\
\hline
\end{tabular}

Keterangan: G1: guru ke 1; G2: guru ke 2; G3: guru ke 3; G4: guru ke 4 
Berdasarkan tabel 1, masingmasing guru yang di observasi memiliki penilaian yang berbeda. Pada guru ke 1 hasil pencapaian maksimal $100 \%$ sedangkan hasil paling rendah yaitu $75 \%$. Walaupun tidak semua indikator memperoleh hasil $100 \%$ tetapi masih masuk dalam kategori sangat tinggi.

Adapun hasil pemahaman guru 2 walaupun pada kategori sagat tinggi terlihat bahwa masih banyak indikator yang belum mencapai $100 \%$. Berdasarkan data yang diperoleh di atas menunjukkan bahwa masih banyak guru yang belum bisa memenuhi sebagian indikator yakni masih banyak yang menyatakan kadangkadang.

Adapun hasil pemahaman guru 3, pencapaian hasil maksimal $100 \%$ lebih banyak di bandingkan dengan hasil $75 \%$. Walaupun tidak semua indikator memperoleh hasil $100 \%$ tetapi masih masuk dalam kategori sangat tinggi dan guru fisika yang ketiga ini lebih memahami setiap indikator dibandingkan guru yang lain.

Adapun hasil pemahaman guru 4, walaupun masih masuk kategori sangat tinggi terlihat bahwa masih banyak indikator yang belum mencapai $100 \%$. Berdasarkan data yang diperoleh pada tabel 1 menunjukkan bahwa masih banyak guru yang belum bisa memenuhi sebagian indikator yakni masih banyak yang menyatakan kadang-kadang. Terkait dengan ini peneliti melakukan observasi yang menunjukkan ada beberapa hal untuk memperkuat data tabel 1. Berdasarkan penelitian dapat disimpulkan dari guru fisika 1 sampai dengan guru fisika 4 walaupun tidak mendapatkan hasil $100 \%$. Tetapi masih masuk dalam kategori sangat tinggi.

Selain itu, hasil wawancara yang dilakukan kepada guru fisika MTs Darul Ulum tentang media pembelajaran, secara umum guru memaparkan bahwa dalam pembelajaran yang diterapkan lebih sering menggunakan media pembelajaran berupa perangkat elektronik seperti infokus, laptop, dan jaringan internet. Pemakaian media pembelajaran yang berupa alat elektronik tersebut dapat membantu/digunakan dalam berbagai metode pembelajaran, seperti demonstrasi dan diskusi kelompok.

Pemakaian alat elektronik juga dapat membantu menyegarkan suasana pembelajaran dengan pemutaran video dan aplikasi pembelajaran (Giyoto et al., 2019; Wibowo et al., 2019). Bahkan pemakaian alat elektronik dapat ditampilkan ditengah metode ceramah. Namun dari paparan salah satu guru, terlihat adanya kekhawatiran tertentu yang dimiliki oleh guru yang turut mempengaruhi pilihan guru untuk mengajar di kelas dengan cara klasik. Kekhawatiran yang dirasakan adalah seputar rentannya penyalahgunaan teknologi informasi dan kesulitan dalam manajemen waktu yang berkaitan dengan karakter peserta didik.

\section{SIMPULAN DAN SARAN}

Kesiapan guru fisika MTs Darul Ulum untuk memulai pembelajaran sudah sesuai dengan acuan silabus dan RPP walaupun belum maksimal, seperti menyiapkan materi, metode, dan media yang akan digunakan dalam pembelajaran. Namun dalam pelaksanaan tidak semua guru melakukan sesuai dengan kurikulum 2013. Hal ini dibuktikan dengan penggunaan media yang minim dan terdapat guru yang masih terpaku pada metode ceramah.

Namun pemahaman guru mengenai penilaian sikap peserta didik belum tepat. Dalam penilaian, kendala yang dihadapi guru adalah menilai keterampilan peserta didik, disebabkan oleh sarana prasarana yang belum memadai. Kesulitan lain yang dihadapi adalah dalam subtitusi nilai moral pada KI I, budaya membaca, dan budaya meneliti. 
Walau begitu sudah ada guru yang berusaha menjalankan ketiga hal yang menjadi ciri khusus dari kurikulum 2013 tersebut dengan baik.

Peneliti selanjutnya harus memperhatikan semua komponen yang ada pada kurikulum yang diterapkan serta menyediakan dan menggunakan media dan bahan ajar yang maksimal pada pembelajaran.

\section{DAFTAR PUSTAKA}

Albantani, A. M. (2015). Implementasi Kurikulum 2013 pada Pembelajaran Bahasa Arab Di Madrasah Ibtidaiyah. Arabiyat, 2(2), 178-191. https://doi.org/http://dx.doi.org/10.15 408/a.v2i2.2127

Baharun, H. (2017). Pengembangan Kurikulum; Teori dan Praktik (Konsep, Prinsip, Pendekatan dan Langkah-langkah Pengembangan Kurikulum PAI. CV Cantrik Pustaka.

Panduan Penyusunan Kurikulum Tingkat Satuan Pendidikan Jenjang Pendidikan Dasar dan Menengah, (2006).

Djuanda, D. (2014). Pembelajaran Sastra di SD dalam Gamitan Kurikulum 2013. Mimbar Sekolah Dasar, 1(2), 191-200.

Giyoto, G., Purnomo, S. L. A., Untari, L., Purnama, S. L. S., \& Asiyah, N. (2019). Gaminguistics: Proposing a Framework on the Communication of Video Game Avatars. Journal of Social Studies Education Research, 10(3), 364-386.

Inzanah, Ibrahim, M., \& Widodo, W. (2014). Pengembangan Perangkat Pembelajaran IPA Berbasis Kurikulum 2013 untuk Melatih Literasi Sains Siswa SMP. Pendidikan Sains Pascasarjana Universitas Negeri Surabaya, 4(1), 549-567.

Josip, P. N., \& Sinambela, M. (2013). Kurikulum 2013
Implementasinya dalam pembelajaran. Generasi Kampus, $6(2)$.

Kemdikbud. (2014). Materi Pelatihan Guru Implementasi Kurikulum 2013 Badan Pengembangan SDM Pendidikan dan Kebudayaan. Penjamin Mutu Pendidikan Kemdikbud.

Kemendikbud. (2013). Permendikbud $81 \mathrm{~A}$ Tahun 2013 Tentang Implementasi Kurikulum 2013. Kementerian Pendidikan dan kebudayaan.

Kemendikbud. (2018). Permendikbud No. 21 Tahun 2016 tentang Standar Isi Kurikulum 2013.

Khoeriyah, Y. (2021). Identifikasi Kurikulum dan Sarana Prasarana Melalui Analisis Swot Dalam Upaya Peningkatan Mutu Pembelajaran di MI Sekolah Alam. Eduvis: Jurnal Manajemen Pendidikan Islam, 6(1), 9-19.

Mulyasa, E. (2013). Pengembangan dan Implementasi Kurikulum 2013. Remaja Rosdakarya.

Oktaviana, D., Jufrida, \& Darmaji. (2016). Penerapan RPP Berbasis Multiple Intelligences untuk Meningkatkan Aktivitas dan Hasil Belajar Fisika Siswa pada Materi Kalor dan Perpindahan Kalor Kelas $X$ MIA 4 SMA Negeri 3 Kota Jambi. Jurnal EduFisika, 1(1), 7-12.

Oktavianti, I., Zuliana, E., \& Ratnasari, Y. (2015). Menggagas Kajian Kearifan Budaya Lokal di Sekolah Dasar Melalui Gerakan Literasi Sekolah. Seminar Nasional, 35-42.

Rakhmawati, S., Muspiroh, N., \& Azmi, N. (2016). Analisis Pelaksanaan Kurikulum 2013 Ditinjau dari Standar Proses dalam Pembelajaran Biologi Kelas X di Sma Negeri 1 Krangkeng. Scientiae Educatia: Jurnal Sains Dan Pendidikan Sains, $5(2)$, 156-164. www.syekhnurjati.ac.di/jurnal/index. 
$\mathrm{php} / \mathrm{sceducatia}$

Wekke, I. S., \& Astuti, R. W. (2017).

Kurikulum 2013 di Madrasah

Ibtidaiyah : Implementasi di Wilayah

Minoritas Muslim. Tadris: Jurnal

Keguruan Dan Ilmu Tarbiyah, 02(1),

33-39.

https://doi.org/10.24042/tadris.v2i1.1

736

Wibowo, A. P., Nababan, M. ., Santosa,

R., \& Kristina, D. (2019).

Reconfiguring Localization Quality Assessment for Video Games. Journal of Social Studies Education Research, 10(3), 346-363.

Wina, D. ., Hindarto, N., \& Prasetyo, A. P. . (2017). Studi Kasus Pendekatan Saintifik dalam Pembelajaran IPA pada Kurikulum 2013 di SMP Negeri 5 Semarang. Journal of Innovative Science Education, 6(1), 1-11.

Yubali, A. (2013). Penilaian Autentik Pada Kurikulum 2013. Seminar Nasional Implementasi Kurikulum 2013, 742-749. 